Князь, Тетяна. «Особливості репрезентації соціальної дійсності засобами фразеології в медійному дискурсі». Лінгвостилістичні студї, вип. 14, 2021, с. 61-70.

Kniaz, Tetiana. "Features of Social Reality Representation Through Phraseology in Media Discourse". Linguostylistic Studies, iss. 14, 2021, pp. 61-70.

УДК 811.161.2'373.7

https://doi.org/10.29038/2413-0923-2021-14-61-70

\title{
ОСОБЛИВОСТІ РЕПРЕЗЕНТАЦІЇ СОЦІАЛЬНОЇ ДІЙСНОСТІ ЗАСОБАМИ ФРАЗЕОЛОГІЇ В МЕДІЙНОМУ ДИСКУРСІ
}

\author{
Тетяна Князь \\ Харківський національний аграрний університет ім. В. В. Докучаєва, \\ Харків, Україна
}

\begin{abstract}
У статті проаналізовано особливості репрезентації соціальної дійсності засобами фразеології української мови в медійному дискурсі. Розглянуто види структурносемантичних трансформацій фразеологізмів: контамінація, субституція, розширення компонентного складу. У медійному дискурсі узуальні й трансформовані фразеологізми влучно характеризують актуальні суспільно-політичні події сьогодення. Прагматичний потенціал фразеологізмів як засіб мовленнєвого впливу на комуніканта, посилення емоційності мовлення реалізовано індивідуально-авторськими трансформаціями.

Ключові слова: фразеологічна одиниця, структурно-семантична трансформація, ідіостиль.
\end{abstract}

\section{FEATURES OF SOCIAL REALITY REPRESENTATION THROUGH PHRASEOLOGY IN MEDIA DISCOURSE}

\section{Tetiana Kniaz}

Kharkiv National Agrarian University named after V. V. Dokuchaiev, Kharkiv, Ukraine

The study of phraseology in media discourse focuses on the individual linguistic worldview of the author represented by lexical and phraseological means that reflect the uniqueness of the author's vision of national-cultural traditions. The scientific research paradigm draws on the principles of anthropocentrism.

The purpose of the research is to analyze the features of the common idioms and transformed phraseological units use as a stylistic device to reflect social reality and to determine their pragmatic potential in media discourse. The methods of descriptive, contextual-interpretive, and transformational analysis have been applied to achieve the research goals.

In media discourse, stable and transformed phraseological units are active linguistic and expressive means of social reality representation. Among the methods of transformation, the most productive are contamination, substitution, and syncopation, which have the strongest effect on the addressee.

The pragmatic potential of phraseology as a means of speech influence is revealed in the individual-authorial features of world perception, processing of the received information, and, accordingly, reaction to it. Journalists, politicians, researchers using a certain PhU

(C) Князь Т., Волинський національний університет імені Лесі Українки, 2021.

Це стаття відкритого доступу на умовах CC BY-NC 4.0 
demonstrate exactly their personal interpretation of the events. In media discourse, phraseology is used as a communicative strategy to achieve a specific goal.

Further research is needed to analyze the linguistic and pragmatic, structural, and semantic aspects of the Ukrainian language phraseological units functioning in media discourse.

Key words: phraseological unit, structural and semantic transformation, idiostyle.

Вступ. Соціокультурна реальність, як правило, інтерпретована низкою дискурсивних практик, що визначені як стандартний спосіб організації мовленнєвої діяльності, реалізованої відповідно до вимог різних типів дискурсу, що $є$ загальноприйнятим для певної соціальнокомунікативної сфери. Науковці мають різні погляди щодо питання репрезентації соціальної дійсності в медійному дискурсі. Спираючись на теорію соціальної відповідальності, традиційно прийнято говорити, що медійні видання передають інформацію достовірно, точно, без викривлення, як дзеркало. Однак, на думку інших дослідників, засоби масової інформації конструюють нову реальність, а не відображають істинну інформацію. Як уважає Л. Гончарова, репрезентація інформації завжди $\epsilon$ індивідуально-авторською або колективно-авторською, «утилітарно-прагматичною картиною світу» (117). У зв'язку із цим особливого значення набуває індивідуально-авторська репрезентація фактів різними лексико-фразеологічними засобами в медійних виданнях (Князь, «Когнітивний» 68).

У лінгвістичних студіях досліджують особливості функціонування фразеологічних засобів у різних типах дискурсу. При цьому питання трансформації фразеологічних одиниць (ФО) не є новим для мовознавства, однак викликає жвавий науковий інтерес (Л. Авксентьєв, О. Андрейченко, Г. Біловус, В. Білоноженко, О. Важеніна, І. Гнатюк, Н. Скиба, I. Тараба, В. Ужченко). Науковці розглядають функціонування узуальних i трансформованих фразеологізмів у системі ідіостилю письменника (Н. Бабич, Ж. Колоїз, Ю. Кохан, Н. Шатілова, Л. Щербачук), характеризують фразеологічні трансформації, інновації текстів політичних дискусій (O. Андрейченко, О. Калякіна, В. Маслова, Л. Пашинська, Т. Свердан, М. Степаненко, О. Шаповал), аналізують мовно-виражальні індивідуальності журналістів (О. Калякіна, I. Лакомська, А. Марковська, В. Мокієнко, К. Серажим, Л. Пархонюк, С. Потапенко). Отже, у світлі одного з визначальних для сучасної наукової парадигми принципу антропоцентризму незмінний науковий інтерес становить дослідження лексико-фразеологічних засобів, що відображають індивідуальну мовну картину світу, специфіку унікальної авторської мовної реалізації як представника національнокультурної традиції.

Мета пропонованої роботи - аналіз особливостей використання узуальних і трансформованих фразеологізмів як засобів відображення соціальної дійсності, а також визначення прагматичного потенціалу ФО в медійному дискурсі. 
Матеріал і методи дослідження. Матеріалом дослідження обрано фразеологізми української мови як засоби відображення соціальної дійсності в сучасних медійних виданнях («BBC News Україна», «Gazeta.ua», «Голос України», «Голос з-над Бугу», «Українська правда», «Український тиждень», а також офіційні портали Верхової Ради України й Міністерства оборони України). Для досягнення визначеної мети використано такі методи: описовий із прийомами наскрізного виписування і систематизації для відбору фактичного матеріалу; контекстуально-інтерпретаційний для увиразнення лінгвальних та екстралінгвальних аспектів функціонування Ф0, для визначення комунікативно-прагматичного змісту ФО в медійному дискурсі; за допомогою методики трансформаційного аналізу схарактеризовано типи трансформацій фразеологізмів як індивідуально-авторських засобів вербалізації інтенцій мовця.

Результати дослідження та дискусія. Слідом за К.Серажим, дискурс визначаємо як «складний соціолінгвістичний феномен сучасного комунікативного середовища, який, по-перше, детермінується (прямо чи опосередковано) його соціокультурними, політичними, прагматичноситуативними, психологічними та іншими (конституюючими чи фоновими) чинниками, по-друге, має „видиму” - лінгвістичну (зв'язний текст чи його семантично значущий та синтаксично завершений фрагмент) та „невидиму” - екстралінгвістичну (знання про світ, думки, настанови, мету адресанта, необхідні для розуміння цього тексту) структуру i, по-третє, характеризується спільністю світу, який „будується” впродовж розгортання дискурсу його репродуцентом (автором) та інтерпретується його реципієнтом (слухачем, читачем тощо)» (13).

Аналіз медійного дискурсу передбачає вивчення мовних, фразеологічних одиниць у контексті прагматичної ситуації спілкування, яка «залучається для визначення зв'язності дискурсу, його комунікативної адекватності, для з'ясування його імплікацій і пресупозицій, для його інтерпретації» (Арутюнова 136). У медійному дискурсі С. Потапенко виділяє номінативно-текстові й текстотвірні тактики. Зокрема, текстотвірні передбачають переміщення у найбільш візуально помітні позиції медіадискурсу (початок заголовків, підзаголовків та абзаців) одиниць, що пов'язані з потребами аудиторії. Номінативно-текстові тактики визначають вибір засобів іменування та характеризації складників подій за умови, коли на позначення різних подій використовуються одні й ті ж самі одиниці (Потапенко 10). Саме прагматичний метод передбачає i аналіз мовних засобів, які в комунікативному акті впливають і спонукають до дій масового реципієнта.

Вивченню дискурсивних стратегій і тактик присвячені напрацювання Т. ван Дейк, О. Билінської, О. Дмитрук, Л. Ільніцької, О. Ісерс, Н. Кондратенко, Л. Стрій. Науковці виділяють переконання й маніпуляцію як важливі види впливу на адресата. Так, Т. ван Дейк, В. Озюменко розмежовують ці види впливу, уточнюючи, що переконання залишає за адресатом вибір, він може 
як брати до уваги ідеї, що нав'язують йому, так і не враховувати їх, робити або не робити дії, до яких його спонукують; у маніпуляції в адресата більш пасивна роль, він не може протистояти маніпуляції й стає ії жертвою (Озюменко 206). Маніпулювання мовними засобами найбільш розповсюджений вид прихованого впливу на свідомість. Це «різновид маніпулятивного впливу, здійснюваний шляхом мистецького використання певних ресурсів мови з метою прихованого впливу на когнітивну й поведінкову діяльність адресата» (Копнина 25).

Мовна особистість упливає на формування світоглядних установок, ціннісних пріоритетів різних категорій суспільства. У медійних виданнях вона репрезентує образ носія мови і національно-культурних традицій, що відіграє певну соціально-культурну роль у суспільстві. Слід підкреслити, що ідіостиль різних типів особистостей (журналістів, політиків, політологів, блогерів) відрізняється характерною для кожного з них моделлю комунікативної поведінки в медійному дискурсі. Мовна особистість журналіста, його когнітивна здатність, особливості світосприйняття, професійний досвід створюють основу під час укладання публікацій в медійних виданнях (Князь, «Когнітивний» 68). 3 метою максимального впливу на реципієнта автор, журналіст апелює передусім до емоцій і почуттів адресата. М. Скуленко зауважує, що емоціями можна лише змусити людину повірити, але неможливо сформувати переконання (42). Переконливість, на нашу думку, досягається завдяки використанню емоційних лексичних, фразеологічних одиниць, які активно функціонують у медійному дискурсі.

Інтерв'ю як інформаційний жанр діалогічного характеру має на меті максимально точно відобразити події в соціумі, «повідомити новину, вплинути на громадську думку» (Пономаренко, Зоська, і Бессараб 77), від імені адресанта передбачає викладення від першої особи. В інтерв'ю 3 Ігорем Колежнюком спостерігаємо використання ФО триматися за спідниџю, уживаному автором у тексті 3 іронією, а саме 3 метою підкреслення залежності від волі жінки, а також відсутності рішучості щодо прийняття рішень. Наводимо ілюстрацію: На думку Ігоря Колежнюка, зрадивши присязі, більшість офіцерів піддалися впливу кримчанок-дружин. Це такі собі вояки, що трималися «за спідницю» (mil.gov.ua, 08 квітня 2017).

Шляхом субституції й розширення компонентного складу утворено фразеологізм розтягування на шматки власних інтересів, у якому актуалізується цілісне значення узуальної ФО тягти ковдру на себе «діяти на догоду власним інтересам; думати лише про себе, бути корисливим» (Словник фразеологізмів 555): Йде поступове паплюження держави та розтягування ї̈ на шматки власних інтересів шахраїв $i$ злочинців (gazeta.ua, 20 червня 2020).

Подібний вид трансформації ілюструє ФО торгівля на крові (пор. узуальна ФО на кістках - «ціною життя або великих зусиль») (Словник фразеологізмів 224). Ю. Тимошенко вдається до використання 
трансформованої ФО з метою дискредитації політичного опонента: Цей хід використала і Юлія Тимошенко, яка зажадала імпічменту для Порошенка «за державну зраду, сприяння ворогу та торгівлю на крові з краӥноюокупантом» (Український тиждень, 26 лютого 2019).

Фіксуємо в медійних виданнях трансформовані ФО віджимання бізнесу; віджим грошей, де лексична заміна і розширення компонентів узуальної ФО бабки збити - «силою забирати гроші; незаконно збагачуватися» (Фразеологічний словник східнослобожанських 28) зумовлені екстралінгвальними факторами, зокрема вчинками, що характерні для представників певних політичних партій. Наводимо ілюстрацію: В каденції 2010 року багато було місцевих бізнесменів, які депутатство використовували як засіб проти віджимання донецькими бізнесу; Ну навіщо «пиляти» бюджет, якщо $\epsilon$ «цивілізовані» схеми віджиму грошей у людей? (Українська правда, 16 серпня 2015).

Продуктивним виявом різновиду трансформації фразеологізмів у медійному дискурсі $\epsilon$ авторська заміна компонентів, що впливає на експресивне забарвлення ФО. Значення «мати нечесний прибуток 3 державних коштів» актуалізується в трансформованих ФО «пиляти» («ділити») бюджет; дерибанити гроші (узуальна ФО набивати (напихати) / набити (напхати) [собі] кишені - «мати нечесний прибуток; наживатися») (Словник фразеологізмів 314). Наприклад: Міша [Радуцький] хоче в наглу бюджет «ділити». Другий день поспіль ЗМІ публікують таку імовірну переписку народного депутата від Павла Павліша із заступником міністра охорони здоров'я Андрієм Семиволосом. Депутат і чиновник обговорюють, як збагатитися в кріслі посадовця і як голова профільного комітету зібрався дерибанити гроші платників податків (Українська правда, 16 січня 2020); Ігор Бондаренко: «Бюджет Закарпаття пиляти не дам» (Голос України, 17 грудня 2019). Як видно, в українському суспільстві ці ФО є дискурсивно продуктивними, оскільки відображають політичну реальність $з$ огляду на частотність фактів незаконного поводження 3 державними грошима.

Журналісти, які оперативно реагують на актуальні події в державі, відображують соціальну реальність, удаються до лексичної заміни компонентів як однієї 3 важливих можливостей виявити потенційні функції ФО - посилення емоційності мовлення, вираження особистого ставлення до конкретної ситуації, події, що відбувається в сучасному суспільстві (Князь, «Трансформації» 25).

Усічення компонентного складу ілюструє ФО заробляння на крові (узуальна ФО кров'ю і потом здобувати, заробляти - «важкими зусиллями, непосильною працею») (Словник фразеологізмів 239). Наприклад: Натомість Володимир Зеленський заявив про 'заробляння на крові' та про штучний розподіл суспільства мовою (Український тиждень, 26 лютого 2019). Думаємо, що маємо справу із структурно-семантичними змінами, оскільки в тексті фразеологічна одиниця заробляння на крові реалізує 
значення «збагачення за рахунок інших», оскільки йдеться про масштабні розкрадання в оборонному комплексі.

У процесі спілкування дослідники виділяють два найбільш важливих типи цілей, що має на увазі комунікант: «перш за все він думає про результат свого повідомлення, тобто про ефективність, і в той же час він прораховує 'ціну' різних підходів, які більшою чи меншою мірою відповідають ситуації спілкування. Це дозволяє розглядати мовну комунікацію в аспекті загальної стратегії (з точки зору мети) і конкретної тактики (з точки зору способу ії реалізації)» (Иссерс 9). Адресант у комунікативному акті має чіткий план ефективного досягнення визначеної мети, орієнтованої на завоювання уваги виборців, на зміну світогляду адресатів, на залякування партнера, його дискредитації тощо.

у медійному дискурсі, зокрема виступах політиків, депутатів спостерігаємо конфліктні стратегії комунікативної поведінки, реалізовані погрозами, звинуваченнями своїх опонентів. Конфліктність підкреслено стилістично зниженою лексикою, зокрема уживанням розмовного фразеологізму сушити сухарі, що використаний 3 метою погрози i підкреслення кримінальної відповідальності в майбутньому. Наприклад, В. Купрій (народний депутат України 8-го скликання): І я вважаю, шановні або нешановні, правильно корупціонери, сушіть сухарі. Скоро ми прийдемо до влади, і вам не буде куди тікати (rada.gov.ua, 20 червня 2018). Значення погрози реалізує узуальна ФО кивати пальцем: «I ще одне - для початку було б непогано повернути цим та іншим 'сепаратистам' кошти, які влада по-бандитськи забрала у місцевого самоврядування. А вже потім кивати пальщем у чийсь бік», - констатував політик [В. Балога] (Закарпаття онлайн, 26 грудня 2013).

Заголовок у будь-якому типі дискурсу (художній, науковий, публіцистичний) має велике значення, оскільки дає попереднє уявлення про порушену в тексті проблему, тему, і саме на нього спирається читацька зацікавленість для подальшого ознайомлення з матеріалом. У заголовку «ЗМІ порахували, скільки разів за 26 років Лукашенко заявляв, що не тримається за владу» автор використовує субституцію як вид структурної трансформації ФО тримається за владу (узуальна ФО вчепитися руками (зубами) за що - «міцно триматися чого-небудь, не відступати від чого-небудь або тримати щось») (Словник фразеологізмів 104) для відображення прагнення президента зберігати за собою право та можливість керувати країною (Українська правда, 21 листопада 2020). Далі журналіст наводить висловлення-цитати пана Лукашенка за весь період керування країною. Фіксуємо трансформований фразеологізм влади наївся, яким політик підкреслює задоволення потреби в керуванні країни, а отже, реалізує прагматичну стратегію впливу на виборців. Наприклад: $Я$ [Лукашенко] вісім років - президент. Повірте, я вже влади наївся стільки, що вам і не снилося (2003 р.); Я їм так говорю: дорогі мої, рідні, я наївся влади, мені шапка Мономаха не потрібна, я не приїжджаю в Кремль, щоб 
схопити якусь стіну і забрати в Білорусь, я не претендую на жодні владні повноваження (2005р.) (Українська правда, 21 листопада 2020). У виступі 2005 року спостерігаємо використання контамінації, об'єднання двох або кількох фразеологізмів в один: наївся влади, мені шапка Мономаха не потрібна, де вжито усічену форму іронічного виразу з драми «Борис Годунов» О. Пушкіна «Важка ти, шапка Мономаха».

Отже, уживаючи фразеологізми як засіб мовленнєвого впливу та підсилюючи дію тактики лінгвостилістичними засобами, політик реалізує визначені маніпулятивні стратегії. Використовуючи раціональну тактику ствердження, адресант демонструє власну впевненість та обізнаність у політичних питаннях різного рівня і розраховує на вдалу реалізацію стратегії самопрезентації, а також прагматичної стратегії впливу на виборців. Стилістичні прийоми повтору ФО наївся влади із року в рік підсилюють дію тактики і схиляють адресата вкотре вірити політикові.

У статті для BBC News про Олеся Гончара - одного із класиків української літератури, професор В. Агеєва використовує низку узуальних і трансформованих фразеологізмів, що свідчить про те, як саме авторка інтерпретує сприйняття подій. Зокрема, для підкреслення великого життєвого досвіду письменника використано узуальну ФО бути на коні [бути] i під конем - «мати великий життєвий досвід» (Фразеологічний словник української 75). Наводимо ілюстрацію: За дебютні «Прапороносці» йому свого часу вручили аж дві (!) сталінські премії. А потому таврували «націоналістичні» новели. Тож побував [Олесь Гончар] i на коні, i під конем. Із читацькою прихильністю було складніше (BВC News Україна, 03 квітня 2018).

Застосування субституції і розширення компонентного складу ФО виживання на владному олімпі свідчить про прагнення автора відобразити складні умови різного періоду життя Олеся Гончара: I далі вже ия історія стає банальною боротьбою за виживання на владному олімпі (BBC News Україна, 03 квітня 2018). Фіксуємо в тексті використання контамінації Ф0 з поєднання двох фразеологізмів без помітних структурних змін: продавати 3-під поли - «таємно, незаконно (продавати чи купувати щось») (Фразеологічний словник української 152) і з рук у рук - «від одного до іншого» (Словник фразеологізмів 467). Наприклад: Собор здобув неймовірну популярність, його передавали з рук у руки, продавали «з-під поли», він мав навіть певний міжнародний розголос (BBC News Україна, 03 квітня 2018).

$\mathrm{y}$ медійних виданнях спостерігаємо частотне використання контамінації. У заголовку «Золоті руки і велике серце у військового медика, нашого земляка Іліана Макачку» (Голос з-над Бугу, 25 березня 2020) поєднано ФО золоті руки - «майстер своєї справи, здібна людина; уміє все зробити» (Фразеологічний словник української 172) і велике серце «хто-небудь дуже добрий, чуйний, здатний перейматися чиїмись переживаннями, горем» (Словник фразеологізмів 483). На нашу думку, саме екстралінгвальні фактори, зокрема бойові дії на Сході України, зміна 
поглядів на життєві цінності, значення професії лікаря, вплинули на виникнення названої ФО.

Заголовок «Не відводити погляд і не опускати руки» (Українська правда, 04 травня 2021) також ілюструє поєднання двох Ф0: не зводити погляду - «пильно дивитися на кого-, що-небудь; стежити, спостерігати за кимсь, чимсь» (Словник фразеологізмів 197) і опускати рук - «стати бездіяльним, байдужим до всього; збайдужіти» (Словник фразеологізмів 354). Слід підкреслити, що такі видозміни $є$ ефективними емоційними активаторами у сприйнятті повідомлюваної інформації, оскільки концентрують увагу та задіюють обізнаність адресатів у царині фразеології для максимально точного декодування повідомлення.

Висновки та перспективи досліджень. Отже, у медійному дискурсі узуальні й трансформовані фразеологізми $\epsilon$ активними мовновиражальними засобами репрезентації соціальної реальності. Серед прийомів трансформацій найпродуктивнішими виявилися контамінація, субституція, а також розширення компонентного складу, що мають максимальні властивості для впливу на комуніканта.

Мова регулює міжособистісні й соціальні відносини, емоції й поведінку людей. Прагматичний потенціал ФО як засіб мовленнєвого впливу на реципієнта, посилення емоційності мовлення реалізовано в індивідуальноавторських трансформаціях. В українському суспільстві трансформовані ФО $\epsilon$ дискурсивно продуктивними, оскільки відображають елементи політичної реальності (незаконність поводження з державними грошима, збагачення, прагнення зберігати за собою владу), міжособистісні стосунки (залежність від жінки, погрози своїм опонентам) тощо. У медійному дискурсі фразеологізми виступають трансляторами культурної, історичної, суспільнополітичної інформації, і виражають систему оцінок політиків, журналістів до подій, ситуацій, особистостей в українському суспільстві сьогодення.

Проведене дослідження не вичерпує порушеної проблематики i передбачає комплексний аналіз фразеологічного матеріалу в медійному дискурсі в лінгвопрагматичному, структурно-семантичному аспектах.

\section{Список використаних джерел}

Верховна Рада України. URL: https://rada.gov.ua

Голос України. URL: http://www.golos.com.ua/

Голос з над Бугу. URL: https://golosznadbugu.com

Закарпаття онлайн. URL: https://zakarpattya.net.ua/

Міністерство оборони України. URL: https://www.mil.gov.ua

Українська правда. URL: https://www.pravda.com.ua

Український тиждень. URL: https://tyzhden.ua/

BBC News Україна. URL: https://www.bbc.com/ukrainian

Gazeta.ua. URL: https://gazeta.ua

Verkhovna Rada of Ukraine. rada.gov.ua

\section{Sources}

Holos Ukrainy. www.golos.com.ua/

Holos z nad Buhu. golosznadbugu.com 
Zakarpattia onlain. zakarpattya.net.ua/

Ministry of Defence of Ukraine. www.mil.gov.ua

Ukrainska pravda. www.pravda.com.ua

The Ukrainian Week. tyzhden.ua/

BBC News Ukraina. www.bbc.com/ukrainian

Gazeta.ua. gazeta.ua

\section{Список використаної літератури}

Арутюнова, Наталья. «Дискурс». Лингвистический энциклопедический словарь. Москва: Советская энциклопедия, 1990, с. 136-7.

Гончарова, Любовь. «Коммуникативные возможности рекламных текстов: праксиологический аспект». Медиалингвистика, вып. 4, 2015, с. 116-21.

Иссерс, Оксана. Коммуникативные стратегии и тактики русской речи. Москва: КомКнига, 2006.

Князь, Тетяна. «Трансформації лексичного наповнення фразеологізмів як свідчення динаміки поняття “заможність"». Лінгвістичні дослідження, вип. 39, 2015, с. 21-7.

Князь, Тетяна. «Когнітивний аспект дослідження фразеологізмів української мови в медійному дискурсі». Лінгвостилістичні студії, вип.13, 2020, с. 62-71. https://doi.org/10.29038/2413-0923-2020-13-62-71

Копнина, Галина. Речевое манипулирование. Москва: Флинта: Наука, 2007.

Озюменко, Владимир. «Медийный дискурс в ситуации информационной войны: от манипуляции - к агрессии». Вестник Российского университета дружбы народов. Серия: Лингвистика, т. 21, № 1, 2017, с. 203-20.

Пономаренко, Людмила, Зоська, Яна, і Бессараб, Анастасія. «Жанрова палітра політичної літератури». Держава та регіони. Серія: Гуманітарні науки, № 3-4, 2012, с. 75-80.

Потапенко, Сергій. Сучасний англомовний медіа-дискурс: лінгвокогнітивний $i$ мотиваційний аспекти. Ніжин, 2009.

Серажим, Катерина. Дискурс як соціолінгвальне явище: методологія, архітектоніка, варіативність. Київ, 2002.

Скуленко, Михаил. Убеждающее воздействие публищистики. Киев, 1986.

Словник фразеологізмів української мови, уклад. В. Білоноженко, І. Гнатюк, В. Дятчук, Н. Неровня, Т. Федоренко. Київ: Наукова думка, 2008.

Фразеологічний словник української мови, уклад. В. Ужченко, Д. Ужченко. Київ: Освіта, 1998.

Фразеологічний словник східнослобожанських і степових говірок Донбасу, уклад. В. Ужченко, Д. Ужченко. Луганськ: Альма-матер, 2005.

\section{References}

Arutjunova, Natal'ja. "Diskurs". Lingvisticheskij jenciklopedicheskij slovar'. Moskva: Sovetskaja jenciklopedija, 1990, pp. 136-7.

Goncharova, Lubov. "Communicative potential of advertising texts: praxeological aspects". Media Linguistics, iss. 4, 2015, pp. 116-21.

Issers, Oksana. Kommunikativnye strategii i taktiki russkoj rechi. Moskva: KomKniga, 2006.

Kniaz, Tetiana. "The Transformation of the Lexical Filling of Phraseological Units as Evidence of Dynamic Concept "Prosperity"”. Lingvistichni doslidzhennja , iss. 39, 2015, pp. 21-7.

Kniaz, Tetiana. "Praseologisms of the Ukrainian Language in the Media Discourse: Cognitive Aspect". Linguostylistic Studies, iss. 13, 2020, pp. 62-71. https://doi.org/10.29038/2413-0923-2020-13-62-71

Kopnina, Galina. Rechevoe manipulirovanie. Moskva: Flinta: Nauka, 2007. 
Ozyumenko, Vladimir. "Media Discourse in an Atmosphere of Information Warfare: From Manipulation to Aggression". Russian Journal of Linguistics, vol. 21, no.1, 2017, pp. 203-20.

Ponomarenko, Liudmyla, Zos'ka, Yana, and Bessarab, Anastasiia. "Genres of political literature". State and Regions. Series: Humanitarian Sciences, no. 3-4, 2012, pp. 75-80.

Potapenko, Serhii. Suchasnyi anhlomovnyi media-dyskurs: linhvokohnityvnyi $i$ motyvatsiinyi aspekty. Nizhyn, 2009.

Serazhym, Kateryna. Dyskurs yak sotsiolinhvalne yavyshche: metodolohiia, arkhitektonika, variatyvnist. Kyiv, 2002.

Skulenko, Mihail. Ubezhdajushhee vozdejstvie publicistiki. Kiev, 1986.

Slovnyk frazeolohizmiv ukrainskoi movy, edited by V. Bilonozhenko, I. Hnatiuk, V. Diatchuk, N. Nerovnia, T. Fedorenko. Kyiv: Naukova dumka, 2008.

Frazeolohichnyi slovnyk ukrainskoi movy, edited by V. Uzhchenko, D. Uzhchenko. Kyiv: Osvita, 1998.

Frazeolohichnyi slovnyk skhidnoslobozhanskykh i stepovykh hovirok Donbasu, edited by V. Uzhchenko, D. Uzhchenko. Luhansk: Alma-mater, 2005.

Стаття надійшла до редколегії 01.03.2021 